\title{
PRESTIDIGITATIONS: \\ INTERFACING WITH PALM-SIZED MEDIA GADGETS
}

People cannot be understood without their things and the way they interact with them. In the case of media technology, interfaces are the site where this interaction takes place: displays allow for viewing, loudspeakers for listening, and the user has to be confident with many operating and control knobs to manipulate the technical parts. In a recent publication, Nokia engineers even stated, that ' (...) the heads of the superpowers, industry and the consumer, meet in a user interface'. In recent years, Nokia has become notorious for its userfriendly designs, and accordingly, this publicised user-centeredness is mainly materialised in interfaces. As the above quote suggests, they are defined as the linchpin in user-machine interaction and thus drive future technology's development. While a conscious interface design is certainly characteristic of the end of the 2oth century - since digital technology has turned interfaces into surfaces that are rather open to personal appropriation - it should be noted that former producers of media technologies deliberately designed subtle interfaces that ultimately changed our interactions as well as our relationship with technology. Interfaces both enable and restrict our interaction with technology, and they represent those parts of media technology users ultimately come in touch with while accessing the actual media content. By incorporating technology into their daily routines, users not only have appropriated technology but also adjusted their own gestures to be able to interact with new interface designs. Moreover, changing interfaces also reflect shifts in our interpretations of technology.

This article focuses on mobile electronic media technology, now commonly dubbed as 'gadgets'. The main examples I will be discussing are pocket radios, pocket recorders, handheld video games and cell phones, the casings and interfaces of which were designed to fit into our pockets and increasingly, our palms. My main sources are the objects themselves, supplemented by data drawn from consumer journals, manuals, advertisements or popular discourse. Most examples are drawn from the (West) German consumer context.

These electronic gadgets represent miniaturised versions of stationary equipment. ${ }^{2}$ Miniaturisation was accompanied by a 'personalisation' of media technology: shrinking interfaces such as miniaturised loudspeakers, their 
substitution by headphones or the tiny screens of handheld games were not designed with family or community consumption in mind, but were aimed at individual users. The miniaturisation of the visual and aural interfaces at the cost of lower sound and image quality is rather obvious, just as the sacrificing of additional features, which would be taking up too much space. But even subtler is the modification of gestures required to operate the gadgets, not to mention the way they are carried on, around or about oneself. This is why this particular aspect will be foregrounded in the following article, whereas other forms of interaction between user and media gadgets will be mentioned only marginally. As we will see, new technology 'hand'ling gestures were gradually introduced. The first innovation was the idea of carrying a miniaturised technology for a longer time-span in one's hand and operating it on the go (or without putting it down). The second innovation, with the advent of the Walkman, was that carrying the technology included intimate wiring with the aural interface. The third innovation consisted in a design of casings and operating buttons that increasingly favoured one-hand control and/or thumb operation including tactile sensations, i.e. the feel of holding and touching the gadget became important design issues. Ultimately, and in parallel with the increasing importance of media gadgets as companions in our daily comings and goings, these developments in the design of operating knobs and surfaces to be touched reflect an important shift in the meaning of media technology: media gadgets materially inhabit our pockets and palms, but on a symbolic level, they have turned into beloved companions to be touched, fondled and used anytime, anywhere.

\section{Pocket radios: new ways of handling and carrying media technology}

As Andreas Fickers has aptly described it, the interaction of radio listeners of the I950 with their radios was manifold. ${ }^{3}$ Not only did the ear listen to the media content, but it also functioned as a control organ to adjust the station. Besides, by focusing their visual sense on the radio station scale, remote domestic listeners could symbolically appropriate the distant sites of radio stations. Furthermore, interfaces such as the so-called 'magic eye' and the flywheel used to select the station provided further sensory satisfaction. In the first instance, a glowing valve made for a fascinating visual control of the fine-tuning. In the other case, the hand's turning movement was translated by the cogwheels of the planetary gear making station selection much easier - in terms of precisely selecting a station, not to mention the sensual experience of turning. In addition to these station scales and wheels, station pushbuttons were developed in the I930s. Some predefined stations could then be selected by pushing a button.

While lacking the magic eye, many West-German portable radios of the I950s surprisingly often were equipped with flywheels and large pushbut- 
tons, even though they took up a lot of space in the interior of the case. The driving principle of the design did not yet emphasise miniaturisation but instead tended to imitate the comfortable operation of domestic appliances. Contrasting with these bigger suitcase-like models, the pocket radio reduced operating and control interfaces to a minimum. It featured neither pushbuttons nor flywheels and radio station scales were mostly visual. The volume and stations were controlled by means of simple thumbwheels that were sunk into the case so that they would not move while being transported in a pocket or a bag. Moreover, the volume control often enabled switching on or off. In West-Germany, by I957, the so-called Partner (Ill. I) and the Peggie were the first portable transistor radios to be mass-produced by the West-German company Telefunken and Akkord respectively. ${ }^{4}$ While the Peggie simulated a handbag and while it was equipped with a carrying handle like all portable radios, the Partner was equipped not only with transistors but also with a printed circuit board. Both were housed in a palm-sized casing without a handle, since it was supposed to be carried either in one's hand, in one's pocket or in a ladies' handbag. However, it sported a dominant stationary wheel on the front that later designs would exchange for a second thumbwheel. Moreover in I957, hence approximately three years after the introduction of the first American pocket transistor radio worldwide - the Regency TR-1 - in I954, the import company Tetron Elektronik $\mathrm{GmbH}$ introduced pocket transistor radios by Sony. 5

With their palm-sized interface and case design, pocket radios were modelled with a completely different use in mind: both size and weight enabled pocket portability, which is why comfortable features, such as the range of pushbuttons, were abandoned. Indeed, the appliances were to be ready-to-use as soon as drawn from a pocket, without further ado. Mainly because of their limited sound performance, they were designed for

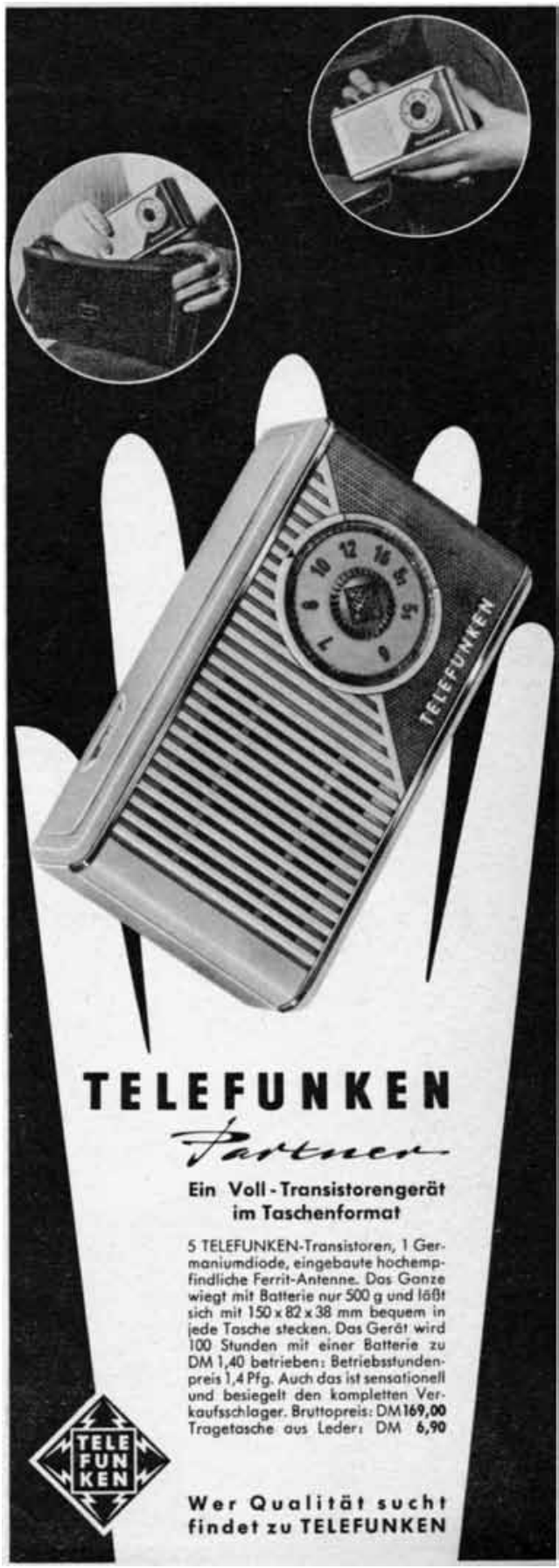

1. The Partner $(15 \times 8,2 \times 3,8 \mathrm{~cm} ; 500 \mathrm{~g})$ on a hand Source: Funkschau, 1957, nr. 11, ad in the front part (without page number). 
individual 'temporary listening' - i.e. e.g. the sportscast from the football pitch or the weather forecast during a mountain hike - rather than for a social event, such as group listening during a picnic. The ad reproduced in illustration I emphasised the 'handyness' of operation as well as the ease with which it could be stowed away. Furthermore, it was styled as a fashion accessory for the modern woman, thus definitely distinguishing pocket radios from the DIY constructions of radio amateurs. But the ad also shows how the owner of the Partner uses the pocket radio, i.e. with both hands, but without putting it down, as would have been the case for contemporary portable radios. One hand holds the appliance, while the index of the other hand turns the thumbwheel. Later models were increasingly designed to cater for one hand use, since the thumb of the hand holding the appliance could reach all the buttons.

Since both the type of use and the way of carrying the small appliance were new, the industry sought to explain the still unfamiliar interaction - e.g. onehand operation and portability close to the body or in a pocket - between user and pocket radio in various ads. Advertising illustrations but also the specialised press regularly demonstrated and/or described the way to hold, carry and operate the pocket radio to consumers who were obviously unfamiliar with the novelty of the gadget. Advertisements regularly pictured the appliance resting in the palm of a hand or held between two fingers. And the captions, explained the appliances, could be operated 'with the finger of the hand holding the radio, since the volume control is positioned beside the station selection wheel. ${ }^{6}$ In this context, the camera was often referred to as a palm-sized media gadget that users had been carrying about them and using in close proximity to the body for quite some time. Beyond the gestures of carrying and holding characteristic of photography, a carrying bag similar to a photographer's bag was offered for the pocket radio. Straps meant that it could be carried on a shoulder or around the neck. For example, consumers who did not want to carry the Siemens $T 1$ from I959 in either their hands or pockets, but 'rather like a camera' could purchase an appropriate leather bag. Thanks to two leather straps of different lengths, the Siemens RT 10 (I960) could 'be carried either as a handbag or as a camera'.7 Thus despite the novelty of the radio's design, it is not surprising that many contemporaries were reminded 'of a camera rather than a radio.' 8

Around 1960 , the pocket transistor radio temporarily became a fashion hit as well as a field of experimentation for miniaturisation. In the long view, it won the third or fourth place within the radio category after a home appliance, a bigger portable radio and a device for the car. Pocket radios established themselves as cheap appliances that could be moved around from the bedside table to the bathroom, the office or the jacket pocket and their main use was for in-between. Ease of handling rather than sound quality prevailed. Hence it was mainly teenagers who purchased the pocket model as their first radio, since it was cheap and met their mobility needs. 


\section{Immersing in technology: one-hand operation recorders and the comeback of the wired listener}

It was during the pocket radio boom around 1960 that for the first time mobile listening was taken into consideration in the design. Thus, the above-mentioned Siemens RT 10 represented a relatively heavy device ( $600 \mathrm{~g})$, but it was capable of receiving several frequency bands, and also offered a short wave reception which had become popular in West-Germany in the course of the I950s. The antenna required for short-wave reception did not protrude but was integrated as a resonant aerial into the carrying straps, so that it would not prove a hindrance while walking. ${ }^{9}$ Most portable radios were also equipped with a single earphone to enable discreet listening in situations such as a bus or train ride. Yet, these earphones did not replace loudspeakers for private music listening since, besides the fact that there seemed to be no demand for private hearing on the go, this type of wiring between ear and radio was suggestive of a hearing aid.

About two decades later, it was exactly this wiring of user and technology that lead to the success of Sony's Walkman (Ill. 2). Its distinctive feature was the restriction to a wearable, play-only unit for headphone listening. According to Shu Ueyama, the head of Sony's publicity department, the Walkman was designed on the basis of the Sony Pressman dictating machine. ${ }^{\mathrm{IO}}$ Its development represented a collective innovation process within the recording department. After an internal restructuring in October 1978 , the latter was forced to come up with a new product idea. The result was the Walkman, a Pressman without a recording function but with stereo sound combined with light earphones. It was launched after less than a year of product development and in I980, it was also introduced to the West-German market.

Before the introduction of the Walkman, it was not by chance that especially travel dictating machines were characterised by miniaturisation and one-hand operation imperatives. Its microphone protruding from the case, such a recorder was designed to be held close to the mouth. As a consumer magazine stated, in order to do this, the appliance should 'rest comfortably in the hand... in every situation (...) and all important functions should be managed by the same hand, and if possible only by the thumb'. However, according to the magazine, few models fulfilled these

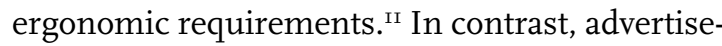
ments for those appliances that could be operated easily with one hand particularly emphasised this

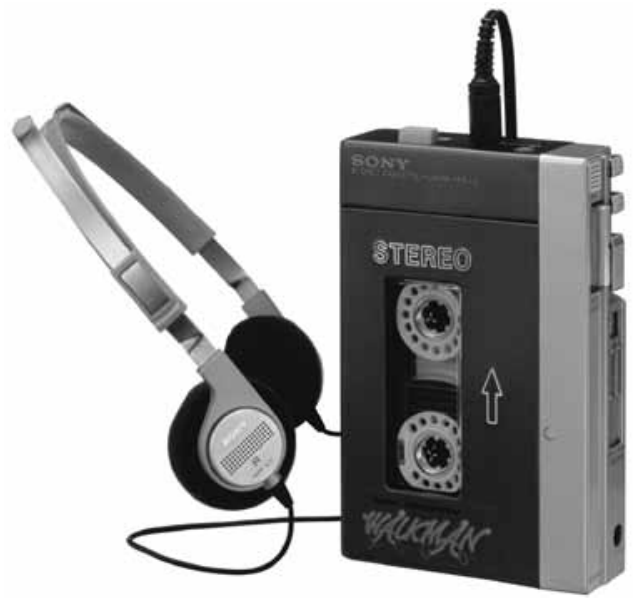

2. The TPS-L2, Sony's first Walkman (Sony Deutschland) 
fact by displaying - in most cases - a man's hand wrapped around the appliance, visibly keeping everything under control.

In the case of the walkman, besides the compact size and a control panel, the most obvious borrowing from the Pressman was the so called 'Talk-Line' (a feature characteristic of most other pocket recorders of the time), which was initially also taken over by competing Walkman clones. If the orange button located on the narrow side of the appliance was pressed down (all other control units were located on the long side), the volume of the music was lowered and, as in the case of a dictating machine, an internal microphone was activated. This microphone transmitted the sound of one's environment to the headphones. Thus, via the push of a button, one could immediately plunge oneself into the surrounding auditive world without having to remove the headphones. As all early walkmans were also equipped with not just one, but two headphone jacks, one could also communicate with one's listening partner through the 'Talk-Line'. A button and a microphone could be located at the same place on the dictating machines, but controlled the recording, as well as the 'start' and 'stop' functions.

Thus buttons shed some light on the unfamiliarity or scepticism triggered by the new way of carrying or 'wearing' the Walkman - i.e. the way in which the earphones were placed directly upon the ears. In the West-German discourse, this orange button was also dubbed the 'communication button', the 'connectionto-the-outside-world-button', the 'message function' or sometimes the 'hot wire' -all metaphors emphasising connectivity to the outside world. ${ }^{\mathrm{I2}}$ The background for this button was the fact that until then, stereo headphones had not been integrated into mobile everyday life, where attention should be paid to traffic noises and other human beings, in order to orient oneself while moving along. The Talk-Line was developed and perceived as a clever technical solution to the auditive problem of headphone-cyborgs, cut off from their environment. ${ }^{13}$ It was only towards the end of 1983 , that Test, a consumer journal, pointed to the fact that one could also simply take off the headphones. ${ }^{\text {I4 }}$ In the aftermath, buttons to technically mediate contact with the outside world gradually disappeared.

With sophisticated new production technologies such as surface-mounted technology and a reduction of components, later Walkman models were hardly bigger than the cassette format. It was the Sony designers who fixed the size of the $W M-2$ - the predecessor of the first Walkman - to the size of a shirt pocket and, accordingly, construction engineers had to develop a new inner design. ${ }^{15}$ Moreover, tiny touch buttons situated on the front of the gadget, increasingly replaced the former pushbuttons. In the long run, such touch keys enabled a more comfortable one-hand control that could be operated by both thumbs and fingers. In the case of Sony, these 'prestidigitations' were particularly noted for the Sports line Walkman models. As these were supposed to accompany sporting activities, they were to 'fit the hand like a glove with every control a short finger's distance away'. ${ }^{16}$ Towards the end of the ig8os, tiny remote commanders were integrated into the headphone wires so that basic functions such as 
the volume control could be operated without taking the walkman out of one's pocket - a feature, that was first introduced in Japan where overcrowded urban subways hardly leave any space for body movement. With later digitalisation, combined with ICD technology, sensitive touch controls and display screens, visualising e.g. the volume or the tracks became a standard in portable audio equipment such as the MD or the MP3 player.

Yet it was mainly the headphone interface that lead to new meanings for music. Firstly, the intimate and immediate interfacing with portable sounds meant that walkmans were used as 'blankies': ${ }^{17}$ The younger generation in particular used the walkman as an emotional prosthesis to cushion themselves away from unreasonable demands emanating from the outside world and to feel secure by means of a self-chosen soundscape. Secondly, the walkman not only meant a different interaction and usage of technology and music but also a different interaction with one's environment. It became normal to impose on the ear - a central and not naturally closeable human interface with our environment - a technological interface connecting users to music instead of to the sounds of their surrounding social field. Due to the intimate, bodily interfacing of technology and human organ, walkman users also perceived differently, since the visual impressions of the environment were devoid of their 'natural' sounds and were accompanied by a self-chosen soundscape.

The Walkman boom brought forth further 'body-portable' audio-designs. For instance, in I980, so-called Roller-Phones, earphone-radios with large circumaural earpads, in which the entire technology was integrated, were imported from the U.s. ${ }^{18}$ At the time, pocket radios also became limited to earphone reception, since the antenna was housed in the earphone cable. ${ }^{19}$ As far as body proximity is concerned, the Bone Fone, also an import from the U.s., even went a step further: it was supposed to be wrapped around the neck like a shawl. The loudspeakers of this music-wearable were located just below the ears so as to mobilise the tactile-bodily sensation of vibration. As opposed to the Walkman, these audio-wearables remained a fashion gimmick that surfed on the popularity of intimate music listening on the go. It was really the influence of the Walkman that normalised the wiring between ear and technology so typical of many media gadgets -from the cell phone to the portable DVD and the MP3player. Moreover, as had been the case a few decades earlier for the camera, the Walkman's design became the point of reference, acknowledged by both technical developers and visionaries, when designing new wearables intimately conjoining the wearer with a technology. ${ }^{20}$

\section{Thumb interactions and tactile sensations: Game Boys and cell phones}

Palm-sized pocket radios and walkmans already fitted in one hand and some features such as volume wheels could be operated single-handedly, using the 
thumb. However, manual interaction with portable audio technology was usually limited to simple operations such as switching on or off and moving the volume control. During most of the listening time, the hardware would remain in the users' pockets or attached to their clothing, leaving both hands free for further activities. ${ }^{2 \mathrm{I}}$ Accordingly, it was the widespread appropriation of handheld videogames and the sms function of cell phones at the end of the 2oth century that finally turned the thumb into the predominant manual organ to interact with the interfaces of the digital age. Furthermore, the tactility of interacting with the technical artefact became a central design feature.

The interactivity of video games demands a constant input from users. While, at first, the controllers of video games also included interfaces inspired by the steering wheel, the pilot stick, or the radio volume button, the control pads of later video games, even when they included joysticks, were manipulated by the tip of the thumb. This novel and inhabitual 'burdening' of the thumb even led to a new syndrome, mostly diagnosed among young people, the socalled 'Nintendo thumb' - a thumb injury caused by the unusual activity of the finger. ${ }^{22}$ Handheld video games were the cutting-edge of thumb-based interface design, which also had to fit in one hand. The LCD pocket games of the I980s, manufactured by the likes of Gakken, Coleco or Bandai, not to mention the Game Q W Watch series by Nintendo were simple games completely encased in hardware about the size of a hand, where predefined graphics moved in the appropriate spaces in front of pre-printed, often colourful backgrounds. But they were conceived so that they could be held between both hands and the thumbs could activate two pushbuttons right and left. ${ }^{23}$ The handheld games of the I990s introduced the changeable cartridge and the dot-matrix representation, but took over the type of performance and gestures executed by users (cf. Ill. 3). Thus, under its tiny screen (diameter: $6 \mathrm{~cm}$ ), the Game Boy from I989 (introduced to Germany in I990) sported a 4-way control pad and two firing buttons controlled by the thumb.

Referring the Game Boy's compact measurements of $15 \times 9 \times 3 \mathrm{~cm}$, the gaming magazine Power Play enthusiastically reported that ' $[\mathrm{t}] \mathrm{hanks}$ to its compact size, the Game Boy rests very comfortably in one's hand'. ${ }^{24}$ In a similar vein, 'Thick Thumbs' was the succinct title that the news magazine Der Spiegel gave a report on a 'gaming computer in calculator format'. ${ }^{25}$ The accompanying photograph showed two kids manipulating the buttons of their gameboys that were linked via a cable for a joint game. Moreover, one could already use Walkman headphones to play with the Game Boy.

Even though in 1992 Nintendo already targeted this 'handful of fun' at adults with the slogan 'on + off' ('Einschalten + Abschalten'), ${ }^{26}$ the Game Boy initially remained part of teenage leisure pursuits. On average, in 1997, there was a Walk- or Discman in $52 \%$ of German children's rooms, in $42 \%$ there was a Game Boy and in 21\% a Tamagotchi - which required 'feeding' and 'care' by pressing a button in order to remain alive. ${ }^{27}$ By the beginning of the 2 Ist cen- 


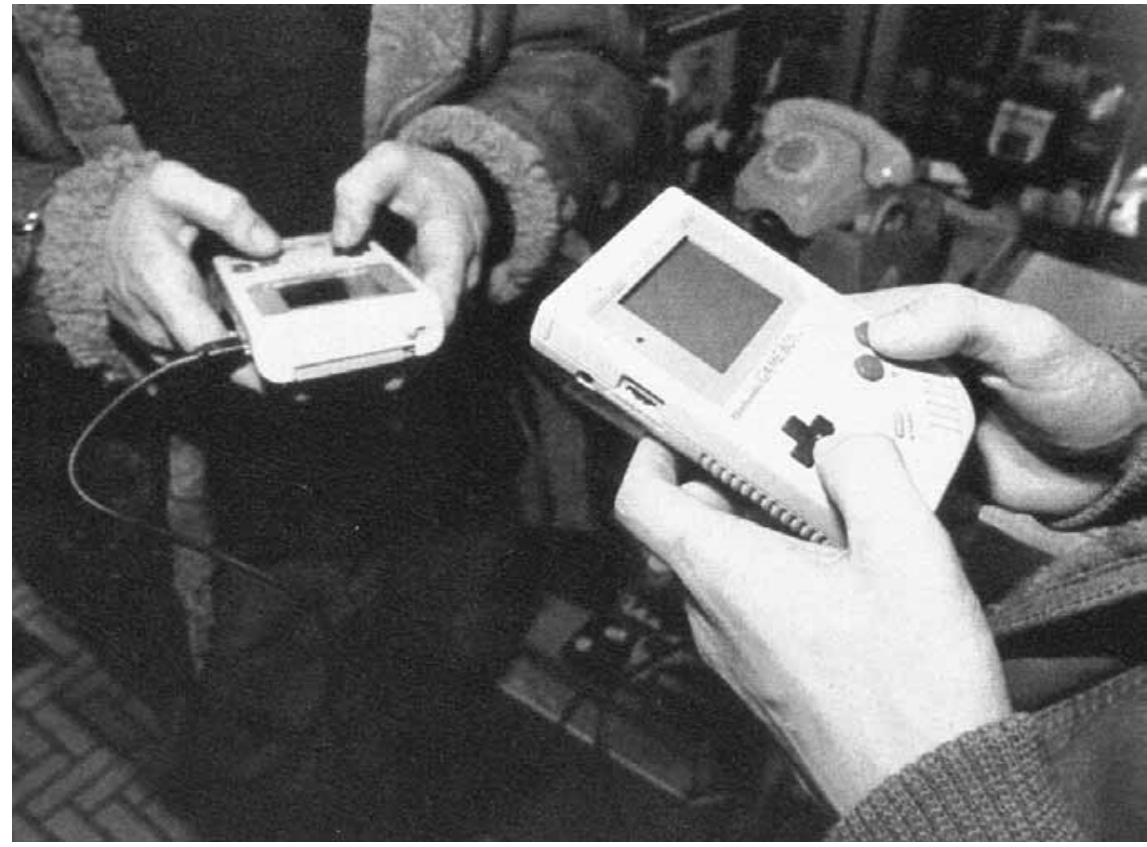

3. Detail of a press photograph under the headline 'Thick thumbs' (1990), showing the thumb operation of the Game Boy. Source: Der Spiegel, 10.12.1990, p. 226 ('Computerspiele: Dicke Daumen')

tury, adults had also joined into the fun of electronic thumb games. Even the conservative bourgeois daily Frankfurter Allgemeine Zeitung extolled the Game Boy as a 'ally to fight the boredom characteristic of so many situations in this world, whether on endless flights, while waiting for a belated train, in a restaurant when the waiter is stressed, in congresses and auditoriums' ${ }^{28}$ And since Nokia first included space for mobile games in 1997 with Snake, cell phones have also become a games medium.

Since the transition from a rather exclusive functional business tool to a chitchat and fun medium for everyone, interfaces and ways of interacting with the cell phone have evolved impressively. Mass mobile phoning really took off in Europe with the introduction of GSM in I992 as well as the rapid cutdown of use costs towards the end of the I99os. This allowed the cell phone to disseminate more rapidly than all other media technologies. In Germany, there are now more cell phone contracts than inhabitants; in fact, cell-phone penetration had already overcome the 50\% hurdle between I999 and 2000. Cell phones have become multi-purpose tools that are used, held and touched regularly, be it to check the status of incoming messages or the time, or to create an sms on the go. Furthermore, due to their interpersonal connectivity feature, cell phones represent an umbilical cord linking consumers to friends and family members.

It was Nokia in 1994 that introduced the break in tradition which was to transform the classical cell phone design into an intimate gadget. According to head designer Frank Nuovo, the former Nokia 2110 was supposed to be '(...) friendly, like a companion' and not mimic 'a little, square, hard box'. ${ }^{29}$ In con- 
trast with other cell phones of the time, the 2110 model was endowed with an enlarged (three lines!) display, the layout of keys broke away from the rigidly ordered pattern reminiscent of a pocket calculator and the menu operating buttons were ergonomically separated from the numbers. Moreover a number of ringtones could be selected and the display was no longer angular but rounded. Thus the cell phone reminded German experts more of a handheld video game than a contemporary mobile telephone. $3^{\circ}$

The 2110's soft keys and its display can be perceived as an early result of Nokia's aspirations towards 'user sensitive' or 'intuitive' design. This development was followed by the so-called 'Navi-Roller', a shuttle dial comparable to a computer trackball. With these menu controls, the logic behind digital, textor icon-based menu steering was transferred to the cell phone. Prior to this, even everyday functions such as the saving of a telephone number demanded the input of complicated number combinations. ${ }^{3 \mathrm{I}}$ These menu controls especially made life easier for those users who had already grown up with digital consumer electronics - since clicking oneself through menus could only be 'intuitive' for computer literate consumers - and they saved the space formerly taken up by single-function keys. In the case of cell phones, Nokia not only paid attention to the 'intuitive' understanding of menus. Beyond that aspect, the cell phone was meant to be used in parallel with other activities, a fact which led to thumb operation, the option of voice activation, and the use of a headset.

From the beginning of the I99os, other producers also oriented themselves towards consumer electronics for their operating interfaces: displays familiar from video games or digital photography, jog dials drawn from audio equipment, or miniaturised joysticks were integrated in cell phones. In I996 already, the technical journal Funkschau noted that cell phones were mutating from 'technologically oriented work appliances' to 'easy to operate everyday appliances, with a 'fun' feel'.32 Sony's CMD-ZI (I997) was characterised by a lateral 'jog dial', typical of the volume control to be found on pocket radios, with which the menu could be navigated using only the thumb of one hand. 'Something more comfortable and more intuitive is hardly to find', a user enthusiastically proclaimed about this way of operation. 33 Operating interfaces such as the 4 -way control pad or the mini-joystick, which appeared around 2000 , were inspired from handheld video games. At the end of the I990s, five-line black and white displays were still the norm, but in 1997 the first colour displays were introduced. They became standards thanks to the introduction of camera phones at the beginning of the $2 \mathrm{Ith}$ century, as well as the practice of mobile gaming, not to mention the popularity of colourful screen savers. The success of differentiated ringtones also pushed producers to pay more attention to the acoustics of cell phones.

Moreover, cell phones were increasingly equipped with features that allowed users to co-shape their 'personal' cell phone, such as the options of creating individual ring tones, of choosing between various screen savers and storing 
personal information or text messages on the phone. Nokia also introduced changeable covers and, besides ringtones, keytones and button pressure could be set according to individual taste. The vibrate function introduced to cell phones at the end of the I990s - after having been tried and tested with pocket pagers - can also be interpreted as a step towards a more tactile interaction with cell phones, a very intimate body interfacing. Indeed, users can literally 'feel' their phone through incoming calls and messages.

During the first half of the I99os, cell phones were generally used with both hands, i.e. the user wrapped one hand around the appliance, while typing with the index of the other hand (cf. Ill. 4). A well-designed cell phone keyboard was supposed to have keys the size of a finger diameter, hence three neighbouring keys were supposed to take up as much space as three fingers held together. 34 While operating these large square buttons still corresponded to the mechanical act of pushing a button, in the course of the

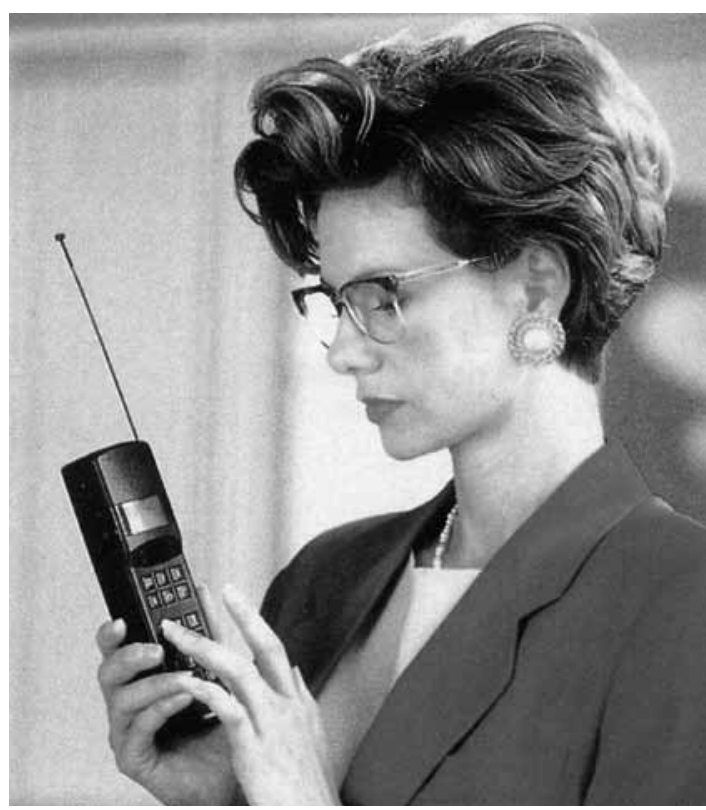

4. Cell phone input at the beginning of the 1990s, here as shown in a PR photography for the Siemens $S$ 1. The big buttons were adapted to the still dominant use of the appliance in a car: once the cell phone was inserted into a car kit, one could easily type a number even when sitting in the driver's seat. Source: Funkschau, 1993, nr. 6, p. 14-18 ('Handtelefone für die D-Netze'), here p. 18 miniaturisation of buttons, the introduction of soft keys and jog dials and the fact that linked to the runaway success of textmessaging, using a cell-phone required more and more button pushing, the actual pushing became more of a sensitive touching, mostly performed with the thumb. The keys are now arranged so that the thumb of the hand holding the cellphone can reach them and a light touch suffices.

Through the massive appropriation of cell phones, the thumb operation of media gadgets, which had been tested over a long period, gradually turned into a widely disseminated 'thumb culture', a culture analysed in recent years by the likes of Sadie Plant or Howard Rheingold upon observing young Asian cell phone users (named 'thumb tribes' or the 'thumb generation' [oyayubi sedai in Japanese]). 35 In that respect, teenagers were also forerunners in Germany. Children of this 'thumbie generation', as a journalist half ironically described them, could 'perform enviable things, that we neither can nor learn how to. For example, they can type their text messages with only two thumbs at an incredible speed. I can't do that. At any rate not half as fast. ${ }^{36}$ The journalist criticised her thumbs as 'comparatively stiff, even though I dutifully play the piano and the guitar'. Nevertheless, Nokia's Communicator, equipped with a mini-keyboard, enabled her to take part in the sms culture. 
When examining the shape and interface design of cell phones, it is obvious that cell phones of the 2ist century are no longer adapted to the automobile environment - the main locus of their use in Germany during the I990s - or the jacket pocket, but to the environment of the hand. They should rest 'haptically correctly' in the palm. Interestingly in Finnish, the palm is called 'Kännykkä' and this term also was chosen to designate 'cell phone'. 37 The cell phone has long outgrown the status of a telecommunicative listening machine, to become a multimedia visual and aural machine, the display of which has accordingly expanded to become the central interface. Just as clothing, cell phones must be as comfortable to 'wear' as they are aesthetically sophisticated, since they have become personal lifestyle indicators. ${ }^{38}$ Beyond these aspects, cell phones are also tactile, intuitive and personalised 'one-hand-tools', because individual users continue to design them, by selecting settings such as ringtones and because the appliances have become intimate treasuries thanks to the input of data such as addresses, telephone numbers, text messaging correspondence, 5. Singular ad for the music and photographs. Thus, proportionately with the work invested in transBlackBerry. Source: New York Times, 14.03 .2004$, p. 26 forming the cell phone into a multimedia treasury, both the value of the cell phone and consumers' identification with it increase.
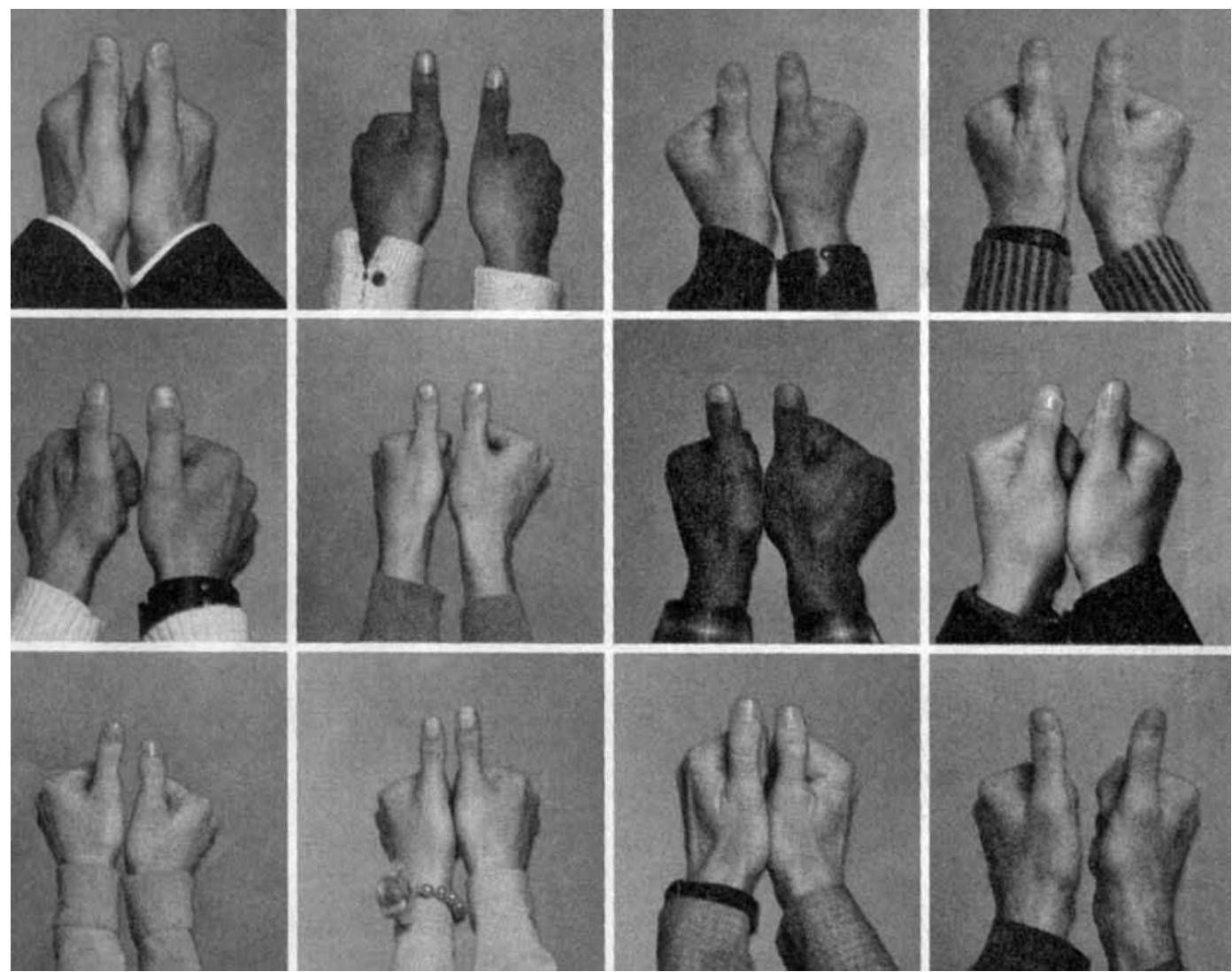
As far as thumb operation is concerned, this mode has also established itself in other gadgets. For example, even if text messaging remains relatively insignificant in the U.S., this function is partially exploited by two-way pagers. 39 Among them, the BlackBerry - introduced in I997 and re-launched a few years later as a smartphone integrating wireless e-mail - gained popularity among the business work force. Many users now hold the BlackBerry in the same way as the Game Boy and feed in data with their two thumbs. In an ad by the wireless carrier Cingular (cf. Ill. 5) the once proletarian 'thumbs up' sign - the thumb was once associated with a practical experience whereas the forefinger represented erudition and learning ${ }^{\circ}$ - iconically represents the interaction with this tool of the 2ist wireless information age and denotes its successful future. Meanwhile, thumb interaction characterises today's digital wireless age: its ubiquitous electronic handheld devices are operated by one or two thumbs rather than by the other fingers. According to Edward Tenner, after its long banishment to the space bar of the typewriter in the interaction between machine and hand, the thumb finally has turned into the "new power digit'. $4^{\mathrm{I}}$ The younger generations especially, operate nearly every knob - be it the doorbell, the buttons of the remote control or the jog dial of the iPod - with the thumb, as it the thumb rather than the index that is the strongest, most mobile and dexterous finger.

\section{Conclusion: Prestidigitations to calm users' eyes, hands and thoughts anytime, anywhere}

For the case of media gadgets, interacting with media concerns more than just choosing, appropriating or consuming media content. These pieces of technology are bodily carried along, be it in one's pocket, be it slung around one's shoulder, or gripped in one's hand. Besides, mobile media consumption implies both the need for a portable casing and the need for interfaces operable while on the go. Thus, this article has focussed primarily on the bodily interactions between users and media gadgets. Secondly, the symbolic level was taken into account since media portables turned into intimate companions of everyday life back home and on the move.

The linchpins of this kind of corporeal and symbolic interaction are the interfaces of media gadgets, as they mediate between user and technology and shape the user-technology interaction. The purposeful design of interfaces and casings - i.e. the surfaces that interface with the users' hand - can be described as a co-agent in technological development. These interfaces mediated new forms of user-technology-relations and interactions, as both users and technology are represented in the respective interface design and they converge in use, mutually shaping each other: New interface designs such as palm-sized casings and thumb-oriented buttons co-evolved with new practices of the manual handling of media gadgets. The most striking example of this type of mutual shaping of material designs and body gestures is the 'thumb culture' that initially arose 
through the new interfaces of electronic and digital media rather than through text-messaging on mobile phones. Indeed, the 'thumb culture' stems from the evolution of gestures required to operate media gadgets and related interfaces. At first the (mechanical) camera served as a reference point for the new ways of handling palm-sized electronics; later on, the walkman and its intimate overlapping of technological (headphone) and human (ear) interfaces became a reference for further ideas about how to merge and even melt body and technology. In terms of the evolution of appliance buttons meant for one-hand or thumb operation, two salient aspects are worth noting: first, it is surprising that - as a compromise between operability and miniaturisation - their dimensions have become way smaller than the ergonomic prescription of an average finger or thumb diameter. Hence, especially men frequently complain that the buttons are definitely too small. $4^{2}$ In the end however, it was users who, turning into cyborgs, adapted to the conditions dictated by their small technical companions and were ready to learn new 'prestidigitations', even going so far as typing text messages on the go. The other noteworthy aspect is that once mechanical push buttons had been replaced by touch keys and touch pads connected to displays, fingers were no longer finely tuned mechanical tools delivering physical input but functioned as a sensorium. This recognition brought forth new interface designs that try to include the skin as a tactile entity. The form and design of the casing were first influenced by the environment of the pocket, then that of the holding hand before taking their cues from the hand as a tactile sensorium, not to mention of course current fashion imperatives and the lifestyle ambitions of projected users. In the early I970s, a Grundig leaflet on cassette recorders for young consumers encouraged the latter to 'try them out, take them in your hand'. 43 'Elegant, modern and handy' were the core attributes already emphasised in publicity for pocket radios and recorders before re-appearing in the advertisements for the wireless digital handhelds of the late 2oth century.

Like the manual tools of the mechanical age, such as the hammer or the screwdriver, they are grasped with one hand while their surfaces and shapes are supposed to fit the user's hand ergonomically. Moreover, they are supposed to be 'intuitive' like the former, but intuition in this case is often limited to the already 'literate'. However, a further characteristic should be mentioned: palmsized media gadgets not only have (re-)introduced the gesture of gripping and manipulating a tool with one hand. At the same time, and besides delivering media content or communication services, these gadgets gradually have turned into friendly companions, and touching them or interfacing with them provides both comfort and security while on the move. People feel reassured while holding their gadgets as well as touching and bodily 'interfacing' with them. While users carve out a private space in public through these interactions, at the same time, their gadgets serve as both emotional companions and sedatives. Their effectiveness can be felt as soon the ear and, for the portables of the late 2oth century, the gaze and the hand are captivated not just by the mediascape 
delivered by the tool but also by the tactile qualities of surfaces and interfaces. In this particular function, they are best compared with objects such as knitting kneedles, prayer beads or stuffed animals rather than their immobile electronic forerunners, since it is actual touching and manipulation that keeps one busy and provides a tactile reinforcement of the self.

\section{Notes}

I T. Keinonen, 'Introduction. Mobile Distinctions', in: Ch. Lindholm, T. Keinonen, H. Kiljander (eds), Mobile usability: how Nokia changed the face of the mobile phone, New York 2003, p. I-7, here p. 2.

2 On the larger issue of the design and consumer culture of portables: H. Weber, Das Versprechen mobiler Freiheit. Zur Kultur- und Technikgeschichte von Kofferradio, Walkman und Handy, Bielefeld 2008.

3 A. Fickers, 'Design als "mediating interface”. Zur Zeugen- und Zeichenhaftigkeit des Radioapparates', in: Berichte zur Wissenschaftsgeschichte 30, 2007, p. I99-213; A. Fickers, “'Sichtbar hörbar”. Radioapparat und Stadt: Knoten im vernetzten Kommunikationsraum', in: C. Zimmermann (ed.), Zentralität und Raumgefüge der Großstädte im 20. Jahrhundert, Stuttgart 2006, p. 83-103.

4 Funktechnik, I957, nr. 9, p. 274-77 ('Drei tragbare Empfänger mit Transistoren').

5 On the TR-1: M. B. Schiffer, The Portable Radio in American Life, Tucson London I99I, p. I76, p. I78; Sony produced its first model, the TR-55, in I955. On the imports of Sony models to West-Germany since I957: Funkschau, I959, nr. I7, p. 408f ('Japanischer U Kw-Transistor-Super'); Funkschau, I957, nr. I7, p. 49I ('Transistor-Taschensuper Sony').

6 Quote from an advertisement for the model Fleetwood, in: Funkschau, I960, nr. 22, p. II38.

7 Ads and reports in: Funkschau, I959, nr. Io, p. 463; Funkschau, I960, nr. II, p. 276 ('u KwTaschensuper ohne Teleskopantenne’) and nr. I5, p. 399 ('Siemens-U Kw-Taschensuper RT Io').

8 Funkschau, I957, nr. 8, p. I97 ('Reiseempfänger - Winke für die Auswahl').

9 Funkschau, I960, nr. II, p. 276 ('u Kw-Taschensuper ohne Teleskopantenne') and nr. I5, p. 399 ('Siemens-U KW-Taschensuper RT IO’).

Io S. Ueyama, 'The selling of the 'Walkman' (or, it almost got called 'Sound - About')', in: Advertising Age, 22.03.I982, M - 2 f and M - 37; P. Kunkel, Digital Dreams: the Work of the Sony Design Center, Kempten I999; P. du Gay, St. Hall, L. Janes, H. Mackay, K. Negus Keith, Doing Cultural Studies. The Story of the Sony Walkman, London I997.

II Test, nr. 2, I976 ('Taschen- und Reisediktiergeräte. Keins ist perfekt.'), p. 3I-38, here p. 32.

I2 Cf. the Test reports until I983 as well as the journal $D M$, I980, nr. I2, p. Io6-III ('Kleine Kisten, großer Klang').

I3 Even advertising emphasised this function. E.g. the mail order catalogue Quelle stated that with the Talk-Line microphone, 'you have always contact to your environment by the push of a button', cf.: Quelle-Katalog, I982/83, p. 864.

I4 Test, I983, nr. II, p. 34-4I ('Guter Sound hat seinen Preis').

I5 Du Gay et al., Doing Cultural Studies.

I6 Cf. the designer Tetsu Mataoka in: Kunkel, Digital Dreams, p. 77.

I7 Sony's own market researchers spoke about the Walkman as a 'blankie', cf.: Ch. Stelzer, 'Musik im Kopf. Der Walkman verändert Hörgewohnheiten', in: Medien und Erziehung, I988, nr. 2, p. 68-74. On the manifold meanings of walkmans: M. Bull, Sounding out the city: personal stereos and the management of everyday life, Oxford 2000.

I8 These were cheap products that were often offered as advertising gimmicks, e.g. by the cigarette brand нв, or as reader bonuses, cf. Hör-Zu, I980, nr. 35, p. 94f, or Hobby, I980, nr. 2I, p. I30.

I9 Telefunken's Radioman (I982) was such a model. Even Koss offered a similar contraption dubbed as Musikbox, cf. Stereo, I982, nr. 4, p. 50-53 ('Mit dem “Koss-Sound” auf Erfolgskurs'). 
20 In I993, Sony's british division for cell phone development was oriented towards the Walkman, cf. Funkschau, I993, nr. 6, p. 49-5I ('Großbritannien. Wird das Mobiltelefon zum Massenartikel?'). In William J. Mitchell's vision on the future City of Bits, the walkman-speared jogger is described as a cyborg whose feet touch the surface of the material world while the ears take part in a virtual world, cf. W.J. Mitchell, City of Bits. Leben in der Stadt des 21. Jahrhunderts, Basel/Boston/ Berlin I996, p. 3I.

2I Some gadgets however, such as Sony's mD player E 44, were designed to be held in the user's hand while listening to the music, cf. Kunkel, Digital Dreams, p. 55.

22 C. Graziano, '“Nintendo Thumb” Points to RSI', in: Wired, I2.03.1998.

23 On handheld video games cf.: J. Gielens, R. Klanten, Electronic Plastic, Berlin 2000.

24 Power Play, I989, nr. 9, p. 8 ('Taschenspieler').

25 Der Spiegel, I0.I2.I990, p. 226 ('Computerspiele: Dicke Daumen').

26 E.g. ad in: Stern, 5.II.I992, p. 57.

27 F. Krotz, U. Hasebrink, Th. Lindemann, F. Reimann, E. Rischkau, Neue und alte Medien im Alltag von Kindern und Jugendlichen. Deutsche Teilergebnisse einer europäischen Studie, Hamburg I999, p. 23. On the Tamagotchi cf.: B. Richard, 'Ständige Bereitschaft. Gestische Standards in der Kommunikation zwischen Mensch und künstlichem Leben', in: H. Sturm (ed.), Geste Q Gewissen im Design, Köln 1998, p. 92-97.

28 Franfurter Allgemeine Zeitung, 27.I2.200I, p. RI ('Der Gameboy. Unterwegs mit Super Mario').

29 Quote by Frank Nuovo, the head of the 70 employees comprising the Nokia design team, in: D. Steinbock, The NOKIA revolution. The story of an extraordinary company that transformed an industry, New York 200I, p. 272.

30 Cf. Funkschau, I994, nr. 7, p. Io-I4 ('Klein, stark und leicht. Fünf neue Handies'), p. II.

3I Consumer tests regularly criticized this, e. g. in: Test, I995, nr. I, p. 34-39 ('Bei Anruf heiße Ohren').

32 Funkschau, I996, nr. 9, p. 76-8I ('Neue Handys für mehr Qualität'), here p. 76.

33 User statement in a German internet portal for buying advice, cf. http://www.ciao.de/Sony_ CMD_ZI_Handy_Test_52I894 (I7.09.2008).

34 V. Everts, Handys: wie Sie telefonieren, wer die Geräte anbietet, Preise und Gebühren, Haar I996, p. 23.

35 S. Plant, On the mobile. The effects of mobile telephones on social and individual life, online: www.motorola.com/mot/doc/o/234_MotDoc.pdf; H. Rheingold, Smart mobs. The next social revolution, Cambridge 2002; P. Glotz, St. Bertschi, Ch. Locke (eds.), Thumb culture. The meaning of mobile phones for society, Bielefeld 2005 .

36 E. Roll, 'Generation Thumbie', in: Süddeutsche Zeitung, 19.8.2003.

37 In colloquial language however, the diminutive 'känny' is used. I would like to thank Petri Paju from Turku for this insight into the Finnish expression.

38 L. Fortunati, J.E. Katz, R. Riccini (eds.), Mediating the Human Body. Technology, Communication, and Fashion, Mahwah, London 2003; B. Tischleder, H. Winkler, 'Portable Media. Beobachtungen zu Handys und Körpern im öffentlichen Raum', in: Ästhetik und Kommunikation 32, 200I, p. 97-I05.

39 Funkschau, 1997, nr. 6, p. $38 \mathrm{f}$ ('Zweiweg-Paging in den UsA'); Rheingold, Smart mobs, p. 23; M. Castells, M. Fernández-Ardèvol, J.L. Qiu, A. Sey, Mobile communication and society: A global perspective, Cambridge 2007, p. 26.

40 E. Tenner, Our own devices. The past and future of bodyt Technology, New York 2003, p. $263 \mathrm{ff}$.

4I Tenner however also hints to the fact that the thumb had already been predominant in the past in the interaction of machine and hand, namely with the advent of the musical keyboard in the I8th century.

42 Cf. for such complaints: Süddeutsche Zeitung Magazin, 3.8.200I, p. 32 ('Mobiltelefon'); Der Spiegel, II.3.2002, p. II7: ('Schafft die Geräte ab').

43 Grundig Revue: Grundig Programm Frühjahr/Sommer 1972, p. 37, in: Deutsches Museum, Archiv, Fs 002253 . 